\title{
PENGARUH STRUKTUR MODAL, PERTUMBUHAN, UKURAN PERUSAHAAN DAN LIKUIDITAS TERHADAP PROFITABILITAS PADA PERUSAHAANPERTAMBANGAN PERIODE 2012-2016
}

\author{
Uyung Sutan Indomo \\ Program Pendidikan Magister Program Studi Magister Akuntansi \\ Sekolah Tinggi Ilmu Ekonomi Indonesia \\ Jl. Kayu Jati Raya No. 11A, Rawamangun - Jakarta 13220, Indonesia \\ uyung.sutan@gmail.com
}

\begin{abstract}
Abstrak - Penelitian ini bertujuan untuk menganalisis pengaruh struktur modal, pertumbuhan, ukuran perusahaan dan likuiditas secara simultan terhadap profitabilitas pada perusahaan pertambangan yang terdaftar di BEI periode 2012-2016. Penelitian ini menggunakan metode penelitian kausal melalui pengujian hipotesa. Populasi penelitian ini adalah 40 perusahaan pertambangan yang terdaftar di BEI periode 2012-2016. Pemilihan sampel dilakukan dengan menggunakan metode non probability sampling dengan teknik purposive sampling sehingga diperoleh sebanyak 36 perusahaan. Jenis data yang digunakan dalam penelitian ini adalah data sekunder, berupa data laporan keuangan yang bersumber dari Indonesian Capital Market Directory (ICMD) dan Bursa Efek Indonesia. Data-data yang diperoleh dari hasil penelitian selanjutnya dianalisis dengan model regresi data panel menggunakan bantuan program software Eviews 9.0.

Ringkasan dari hasil penelitian ini adalah pertama, struktur modal terbukti berpengaruh negatif signifikan terhadap profitabilitas. Kedua, pertumbuhan perusahaan berpengaruh positif signifikan terhadap profitabilitas. Ketiga, ukuran perusahaan berpengaruh positif dan tidak signifikan terhadap profitabilitas. Keempat, likuiditas berpengaruh negative signifikan terhadap profitabilitas. Berdasarkan hasil penelitian yang dilakukan, terbukti bahwa struktur modal, pertumbuhan perusahaan dan likuiditas memiliki pengaruh yang signifikan terhadap profitabilitas perusahaan. Sehingga disarankan kepada pihak investor hendaknya memastikan pihak manajerial perusahaan mengelola struktur modal dengan seefisien dan seefektif mungkin serta mempertimbangkan bagaimana manajerial memanfaatkan dan mengelola segala sumber daya yang dimiliki perusahaan untuk meningkatkan pertumbuhan usahanya dan hendaknya lebih memperhatikan likuiditas perusahaan karena terbukti berpengaruh terhadap profitabilitas perusahaan.
\end{abstract}

Kata Kunci Struktur Modal, Pertumbuhan, Ukuran Perusahaan, Likuiditas dan Profitabilitas 


\section{PENDAHULUAN}

Krisis ekonomi global yang terjadi akibat penguatan mata uang dolar Amerika Serikat (USD) dan kebijakan Pemerintah Tiongkok yang mendevaluasi Yuan membuat Indonesia terkena dampaknya. Selain berdampak pada terdepresiasinya rupiah hingga menyentuh angka Rp14.200 per USD, dampak krisis global juga memberi pengaruh pada pertumbuhan ekonomi Indonesia yang melambat, dari 4,71 persen pada kuartal pertama 2015 menjadi 4,67 persen pada kuartal kedua di tahun yang sama. Penurunan pertumbuhan ekonomi dunia juga mengalami perlambatan, dan hal ini berdampak terhadap penurunan harga komoditas internasional sebagai akibat menurunkan permintaan. Salah satu sektor industri yang terkena dampak secara langsung dari krisis global saat ini adalah perusahaan sektor pertambangan, dimana perusahaan sektor pertambangan lebih mengandalkan pendapatannya dari hasil penjualan ekspor. Sehingga akhirnya berdampak terhadap penurunan tingkat profitabilitas.

Struktur modal merupakan salah satu keputusan keuangan yang kompleks karena berhubungan dengan variabel keputusan keuangan lainnya. Untuk mencapai tujuan perusahaan dalam memaksimalisasi kekayaan pemilik, manajer keuangan harus dapat menilai struktur modal perusahaan dan memahami hubungannya dengan resiko, hasil atau pengembalian dan nilai. Keputusan struktur modal perusahaan yang buruk dapat menimbulkan biaya modal yang tinggi. Oleh karena itu, diperlukan keputusan keuangan yang efektif untuk dapat merendahkan biaya modal, yang akhirnya akan meningkatkan nilai perusahaan (Sundjaja dan Barlian, 2012).

Keputusan dalam struktur modal semakin diperlukan khususnya dalam kondisi krisis global seperti sekarang ini, dimana capital outflow lebih banyak dibandingkan capital inflow sehingga biaya modal menjadi mahal. Kisis keuangan yang terjadi terjadi di beberapa Negara telah berkembang menjadi masalah serius. Gejolak tersebut mulai mempengaruhi stabilitas ekonomi global di beberapa kawasan. Hampir semua negara di dunia menganut sistem pasar bebas sehingga terkait satu sama lain. Aliran dana bebas keluar masuk dari satu negara ke negara lain dengan regulasi moneter tiap negara yang beragam. Krisis global ini menyebabkan larinya modal dari tempat yang kurang aman menuju yang dianggap lebih aman.

Lebih lanjut, Safrida (2008) menyatakan saat ini dunia usaha tergantung pada masalah pendanaan, dunia usaha mengalami kemunduran yang diakibatkan dari Jurnal STEI Ekonomi Vol. 28 No. 02, Desember 2019 
banyaknya lembaga-lembaga keuangan yang mengalami kesulitan keuangan sebagai adanya kemacetan kredit pada dunia usaha tanpa memperhitungkan batas maksimum pemberian kredit dimasa lalu oleh perbankan dan masalah kelayakan kredit yang disetujui. Upaya mengantisipasi kondisi tersebut, maka manajer keuangan perusahaan harus berhati-hati dalam menetapkan struktur modal perusahaan, dengan adanya perencanaan yang matang dalam menentukan struktur modal diharapkan perusahaan dapat meningkatkan nilai perusahaan dan lebih unggul dalam menghadapi persaingan bisnis.

Beberapa penelitian telah dilakukan terhadap struktur modal, antara lain, Dawar (2015) menemukan bahwa struktur modal berpengaruh negatif terhadap kinerja keuangan. Akeem (2014) juga menemukan hal yang sama bahwa terdapat hubungan negatif antara struktur modal dengan kinerja perusahaan.

Berdasarkan pada pemaparan latar belakang di atas, penelitian ini bermaksud menguji "Pengaruh Struktur Modal, Pertumbuhan, Ukuran Perusahaan dan Likuiditas terhadap Profitabilitas pada Perusahaan Pertambangan periode 2012-2016”.

\section{KAJIAN PUSTAKA}

\subsection{Teori Sinyal (Signaling Theory)}

Teori dasar dalam penelitian ini yaitu menggunakan Signaling Theory (Teori Sinyal). Signaling Theory (Teori Sinyal) merupakan teori yang menyatakan adanya dorongan yang dimiliki oleh para manajer perusahaan yang memiliki informasi yang baik mengenai perusahaan, sehingga para manajer akan terdorong untuk dapat menyampaikan informasi mengenai perusahaan tersebut kepada para calon investor, yang bertujuan agar perusahaan dapat meningkatkan nilai perusahaan tersebut melalui sinyal dalam pelaporan pada laporan tahunan perusahaan (Leland dan Pyle, 1977) dalam (Scott, 2012:475).

\subsection{Struktur Modal}

Struktur Modal adalah proporsi dalam menentukan pemenuhan kebutuhan belanja perusahaan dimana dana yang diperoleh menggunakan kombinasi atau paduan sumber yang berasal dari dana jangka panjang yang terdiri dari dua sumber utama yakni yang berasal dari dalam dan luar perusahaan (Rodoni dan Ali, 2010). 


\subsection{Pertumbuhan Perusahaan}

Menurut Sunarto dan Budi (2009) pertumbuhan perusahaan menggambarkan tolok ukur keberhasilan perusahaan. Keberhasilan tersebut juga menjadi tolok ukur investasi untuk pertumbuhan pada masa yang akan datang. Titman dan Wessel (1988) mengatakan bahwa kesempatan tumbuh sebagai perusahaan merupakan proxy yang tepat untuk biaya agency hutang. Mereka menyarankan bahwa tendensi untuk melakukan investasi adalah terjadi pada perusahaan-perusahaan yang berada dalam industri yang sedang tumbuh.

\subsection{Ukuran Perusahaan}

Ukuran perusahaan merupakan ukuran atas besarnya aset yang dimiliki perusahaan sehingga perusahaan besar umumnya mempunyai total aktiva yang besar pula. Perusahaan besar dapat lebih mudah untuk mengakses pasar modal dibandingkan dengan perusahaan yang kecil. Semakin besar ukuran perusahaan semakin mudah untuk mendapatkan modal eksternal dalam jumlah yang lebih besar, sehingga investor tertarik untuk menanamkan modalnya pada perusahaan tersebut sehingga menaikan nilai perusahaan. Dengan tersedianya dana tersebut maka memberi kemudahan perusahaan untuk melaksanakan peluang investasi (Suanarto dan Budi, 2009).

\subsection{Likuiditas}

Menurut Brealey, et al. (2008:77) Rasio likuiditas juga memiliki beberapa karakteristik yang kurang diinginkan. Karena asset dan kewajiban jangka pendek mudah diubah, ukuran likuiditas dapat dengan cepat berubah menjadi ketinggalan zaman. Menurut Fahmi (2012) likuditas adalah ukuran yang umum digunakan atas solvensi jangka pendek, kemampuan suatu perusahaan memenuhi kebutuhan ketika jatuh tempo. Hasil penelitian Kaur dan Sily (2013) dan Afriyanti (2011) mendapatkan hasil bahwa current ratio berpengaruh negatif dan signifikan terhadap ROI.

\subsection{Profitabilitas}

Menurut Brealey, et al. (2008: 80) Profitabilitas mengukur fokus pada laba perusahaan. Perusahaan besar diharapkan mengahasilkan lebih banyak laba daripada perusahaan kecil, jadi untuk memfasilitasi perbandingan lintas perusahaan, total laba diekspresikan dalam basis per-dolar.Menurut Van Horne dan Wachowicz (2012) rasio rentabilitas disebut juga sebagai rasio profitabilitas yaitu rasio yang digunakan untuk mengukur kemampuan perusahaan dalam memperoleh laba atau keuntungan. 
Profitabilitas suatu perusahaan mewujudkan perbandingan antara laba dengan aset atau modal yang menghasilkan laba tersebut.

\subsection{Kerangka Pemikiran}

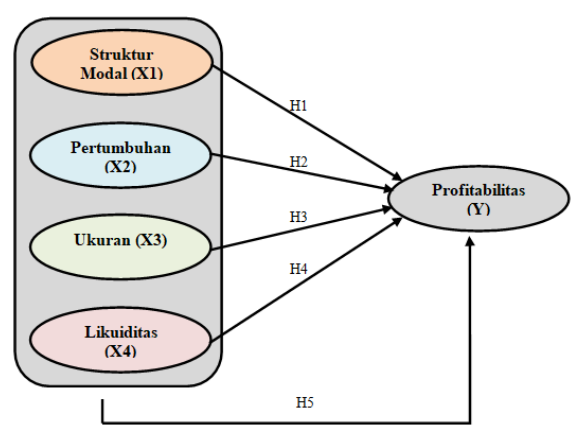

Gambar 1. Kerangka Pemikiran

\subsection{Hipotesis}

Hipotesis dari penelitian ini sebagai berikut:

$\mathrm{H} 1=$ Struktur modal berpengaruh negatif terhadap profitabilitas

$\mathrm{H} 2=$ Pertumbuhan perusahaan berpengaruh positif terhadap profitabilitas

H3 = Ukuran Perusahaan berpengaruh positif terhadap profitabilitas

$\mathrm{H} 4=$ Likuiditas berpengaruh positif terhadap profitabilitas

H5 = Struktur modal, pertumbuhan perusahaan, ukuran perusahaan, dan likuiditas secara bersama-sama berpengaruh negatif terhadap profitabilitas

\section{METODE PENELITIAN}

Objek penelitian adalah pengaruh struktur modal, pertumbuhan perusahaan, ukuran perusahaan, dan likuiditas terhadap profitabilitas pada perusahaan pertambangan yang terdaftar di Bursa Efek Indonesia (BEI) periode 2012-2016. Penelitian ini menggunakan metode penelitian kausal dan jenis data yang digunakan dalam penelitian ini adalah data sekunder, yang merupakan data laporan keuangan yang bersumber dari Indonesian Capital Market Directory (ICMD) dan Bursa Efek Indonesia. Populasi penelitian ini adalah 40 perusahaan pertambangan yang terdaftar di BEI periode 20122016. Pemilihan sampel dilakukan dengan menggunakan metode non probability sampling dengan teknik pengambilan sampel dilakukan secara purposive sampling.

Metode analisis data yang digunakan dalam penelitian ini adalah model regresi data panel (kombinasi time series dan cross section) dengan menggunakan bantuan program aplikasi statistik komputer Eviews 9. 
Tabel 1. Variabel dan Pengukuran

\begin{tabular}{|c|c|c|}
\hline Dimensi & Indikator & Skala \\
\hline Struktur Modal & $\begin{array}{c}\text { DER } \\
\text { DER }=\frac{\text { Hutang }}{\text { Ekuitas }}\end{array}$ & Rasio \\
\hline $\begin{array}{c}\text { Pertumbuhan } \\
\text { Perusahaan }\end{array}$ & $\begin{array}{c}\text { Sales Growth } \\
\text { Growth }=\frac{\text { Sales }_{\mathrm{t}}-\text { Sales }_{\mathrm{t}-2}}{\text { Sales }}\end{array}$ & Rasio \\
\hline Likuiditas & $\begin{array}{c}\text { Current Ratio } \\
C R=\frac{\text { Harta Lancar }}{\text { Hutang Lancar }}\end{array}$ & Rasio \\
\hline Ukuran Perusahaan & $\begin{array}{c}\text { Size } \\
\text { Sire }=\ln (\text { Total Aset })\end{array}$ & Rasio \\
\hline Profitabilitas & $\begin{array}{c}\text { ROE } \\
\text { Laba Bersih }\end{array}$ & Rasio \\
\hline Ekuitos & \\
\hline
\end{tabular}

Dalam regresi data panel dikenal dua macam pendekatan yang terdiri dari pendekatan efek tetap (fixed effect), dan pendekatan efek random (random effect). Adapun model dapat di rumuskan sebagai berikut :

$$
\mathrm{Y}=\beta 0+\beta 1 \mathrm{X} 1+\beta 2 \mathrm{X} 2+\beta 3 \mathrm{X} 3+\beta 4 \mathrm{X} 4 \mathrm{e}
$$

Dimana:

$\mathrm{Y}=$ Profitabilitas

$\beta 0=$ Konstanta

$\mathrm{X} 1=$ Struktur Modal

$\beta 1=$ Koefisien Regresi Variabel X1

$\mathrm{X} 2=$ Pertumbuhan Perusahaan

$\beta 2=$ Koefisien Regresi Variabel X2

$\mathrm{X} 3=$ Ukuran Perusahaan

$\beta 2=$ Koefisien Regresi Variabel X3

$\mathrm{X} 4=$ Likuiditas

$\beta 4=$ Koefisien Regresi Variabel X4

$\mathrm{e}=$ error

\section{HASIL PENELITIAN}

\subsection{Pemilihan Model Terbaik Dengan Uji Hausman}

Hausman test dilakukan untuk memilih model mana yang lebih baik, apakah menggunakan fixed effect model atau random effect model. Hipotesis dalam pengujian Hausman test adalah sebagai berikut:

H0: Model mengikuti Random Effect Model 
H1: Model mengikuti Fixed Effect Model

Alpha $=5 \%$

Ketentuan : Tolak H0 jika nilai $p$-value < alpha

Berikut adalah hasil yang diperoleh dari pengujian Hausman test yang dilakukan dengan menggunakan software EViews:

Tabel 2. Hasil Uji Hausman Test

\begin{tabular}{lccc}
\hline \hline Test Summary & $\begin{array}{c}\text { Chi-Sq. } \\
\text { Statistic }\end{array}$ & $\begin{array}{c}\text { Chi-Sq. } \\
\text { d.f. }\end{array}$ & Prob. \\
\hline \hline Cross-section random & 13.301447 & 4 & 0.0099 \\
\hline \hline
\end{tabular}

Pada tabel di atas, dapat dilihat bahwa nilai probability pada test cross section random memperlihatkan angka bernilai 0,0099 lebih kecil dari alpha $(0,05)$. Sehingga keputusan yang diambil pada pengujian Hausman test ini yaitu $\mathrm{H} 0$ ditolak dan model mengikuti metode fixed effect model.

\subsection{Pengujian Hipotesis dengan Fixed Efek Model}

Hasil olahan data yang digunakan dalam analisis statistik adalah uji metode fixed effect model, karena berdasarkan hasil hausman test menunjukkan bahwa fixed effect model lebih baik dibandingkan dengan metode random fixed model. Hasil estimasi metode fixed effect sebagai berikut:

Tabel 3. Hasil Estimasi Metode Fixed Efek Model

\begin{tabular}{|c|c|c|c|c|}
\hline Variable & Coefficient & Std. Error & t-Statistic & Prob. \\
\hline$\overline{\mathrm{C}}$ & -0.160430 & 0.259488 & -0.618258 & 0.5374 \\
\hline $\mathrm{X} 1$ & -0.093196 & 0.012184 & -7.649246 & 0.0000 \\
\hline $\mathrm{X} 2$ & $3.94 \mathrm{E}-05$ & $1.18 \mathrm{E}-05$ & 3.340911 & 0.0011 \\
\hline $\mathrm{X} 3$ & 0.024540 & 0.017374 & 1.412448 & 0.1600 \\
\hline $\mathrm{X} 4$ & -0.000442 & 0.000134 & -3.287705 & 0.0013 \\
\hline \multicolumn{2}{|l|}{ R-squared } & 0.671494 Mea & ndent var & 0.187356 \\
\hline \multicolumn{2}{|l|}{ Adjusted R-squared } & 0.579981 & S.D. dependent var & 0.496018 \\
\hline \multicolumn{2}{|l|}{ S.E. of regression } & \multicolumn{2}{|c|}{0.305746 Sum squared resid } & 13.08729 \\
\hline \multicolumn{2}{|l|}{ F-statistic } & \multicolumn{2}{|c|}{ Durbin-Watson stat } & 1.792323 \\
\hline \multicolumn{2}{|l|}{$\operatorname{Prob}($ F-statistic $)$} & \multicolumn{2}{|l|}{0.000000} & \\
\hline \multicolumn{2}{|l|}{ R-squared } & \multicolumn{2}{|l|}{0.547884} & 0.086761 \\
\hline \multicolumn{2}{|l|}{ Sum squared resid } & \multicolumn{2}{|c|}{ 13.09720 Durbin-Watson stat } & 2.214457 \\
\hline
\end{tabular}

Berdasarkan Tabel 3, diperoleh persamaan regresi berganda sebagai berikut:

$$
\mathrm{Y}=\mathbf{- 0 , 1 6 0 4 3 0}-0.093196 \mathrm{X} 1+3.94 \mathrm{E}-05 \mathrm{X} 2+0.024540 \mathrm{X3}-0.000442 \mathrm{X4}+\mathrm{e}
$$

Dari model persamaan di atas, dapat di jelaskan bahwa metode fixed effect model menunjukan apabila Struktur Modal (X1), Pertumbuhan Perusahaan (X2), 
Ukuran Perusahaan (X3) dan Likuiditas (X4) tidak ada atau bernilai tetap maka Profitabilitas (Y) akan mengalami penurunan sebesar 0,160430. Sementara itu, Struktur Modal dan Likuiditas memiliki hubungan negatif terhadap Profitabilitas, yang artinya apabila Struktur Modal dan Likuiditas mengalami peningkatan maka Profitabilitas akan mengalami penurunan. Sedangkan untuk variabel Pertumbuhan Perusahaan dan Ukuran Perusahaan memiliki hubungan positif yang artinya jika Pertumbuhan Perusahaan dan Ukuran Perusahaan mengalami peningkatan maka disusul dengan kenaikan Profitabilitas.

\subsubsection{Koefisien Determinasi (R2)}

Hasil perhitungan koefisien determinasi tersebut dapat terlihat pada Tabel 3 sebelumnya.

\section{R-squared sebesar 0,671494}

Nilai R2 adalah sebesar 0,671494 (67,14\%) menunjukkan bahwa besar pengaruh variabel Struktur Modal (X1), Pertumbuhan Perusahaan (X2), Ukuran Perusahaan (X3) dan Likuiditas (X4) terhadap Profitabilitas (Y) yang dapat diterangkan oleh model persamaan ini adalah sebesar $67,14 \%$ dan sisanya sebesar $32,86 \%$ dipengaruhi oleh faktor-faktor lain yang tidak dimasukkan dalam model regresi.

\subsubsection{Uji $F$}

Hasil perhitungan Uji $\mathrm{F}$ pada penelitian ini dapat dilihat pada Tabel 3 sebelumnya:

$$
\begin{array}{ll}
\text { F-statistic } & 7,337727 \\
\text { Prob(F-statistic) } & 0,000000
\end{array}
$$

Dari hasil analisis uji F pada tabel 4.3, dapat diketahui bahwa nilai F-statistic yang diperoleh sebesar 7,337727 dengan nilai Prob (F-statistic) lebih kecil dari tingkat signifikasi $5 \%(0,000<0,05)$. Dengan demikian H5 diterima artinya Struktur Modal, Pertumbuhan Perusahaan, Ukuran Perusahaan, dan Likuiditas secara simultan berpengaruh terhadap Profitabilitas.

\subsubsection{Uji $t$}

Hasil pengujian parsial dapat dijelaskan sebagai berikut: 
Tabel 4. Hasil Uji t

\begin{tabular}{ccc}
\hline \hline Variable & t-Statistic & Prob. \\
\hline \hline C & $-0,618258$ & 0,5374 \\
X1 & $-7,649246$ & 0,0000 \\
X2 & 3,340911 & 0,0011 \\
X3 & 1,412448 & 0,1600 \\
X4 & $-3,287705$ & 0,0013 \\
\hline \hline
\end{tabular}

\section{Pengujian Hipotesis 1}

Hipotesis pertama yang diajukan dalam penelitian ini adalah:

H1 = Struktur Modal berpengaruh negatif terhadap Profitabilitas

Dari hasil penelitian diperoleh nilai koefisien regresi untuk variabel Struktur Modal sebesar -0,093196 dengan nilai signifikansi sebesar 0,0000, dimana nilai signifikansi tersebut lebih kecil dari 0,05 $(0,0000<0,05)$. Dengan demikan H1 diterima, artinya Struktur Modal berpengaruh negatif dan signifikan terhadap Profitabilitas.

\section{Pengujian Hipotesis 2}

Hipotesis kedua yang diajukan dalam penelitian ini adalah:

$\mathrm{H} 2=$ Pertumbuhan Perusahaan berpengaruh positif terhadap Profitabilitas

Dari hasil penelitian diperoleh nilai koefisien regresi untuk variabel Pertumbuhan Perusahaan sebesar 3,94E-05 dengan nilai signifikansi sebesar 0,0011, dimana nilai signifikansi tersebut lebih kecil dari 0,05 $(0,0011<0,05)$. Dengan demikan H2 diterima, artinya Pertumbuhan Perusahaan berpengaruh positif dan signifikan terhadap Profitabilitas.

\section{Pengujian Hipotesis 3}

Hipotesis ketiga yang diajukan dalam penelitian ini adalah:

H3 = Ukuran Perusahaan berpengaruh positif terhadap Profitabilitas

Dari hasil penelitian diperoleh nilai koefisien regresi untuk variabel Ukuran Perusahaan sebesar 0,024540 dengan nilai signifikansi sebesar 0,1600, dimana nilai signifikansi tersebut lebih besar dari 0,05 (0,1600 > 0,05). Dengan demikan H3 ditolak, artinya Ukuran Perusahaan berpengaruh positif dan tidak signifikan terhadap Profitabilitas.

\section{Pengujian Hipotesis 4}

Hipotesis keempat yang diajukan dalam penelitian ini adalah: 
H4 = Likuiditas berpengaruh positif terhadap Profitabilitas

Dari hasil penelitian diperoleh nilai koefisien regresi untuk variabel Likuiditas sebesar -0,000442 dengan nilai signifikansi sebesar 0,0013, dimana nilai signifikansi tersebut lebih kecil dari 0,05 $(0,0013<0,05)$. Dengan demikan H4 ditolak, artinya Likuiditas berpengaruh negatif dan signifikan terhadap Profitabilitas.

\subsection{Pembahasan}

Berdasarkan hasil penelitian yang telah dilakukan, diperoleh bahwa variabel struktur modal memiliki pengaruh negative dan signifikan terhadap profitabilitas pada perusahaan pertambangan. Struktur modal sangat erat kaitannya dengan kemampuan perusahaan dalam memperoleh laba (profitabilitas) karena kegiatan perusahaan baik operasional maupun non operasional pada dasarnya dilakukan untuk memperoleh keuntungan. Hasil penelitian ini didukung oleh Novita (2015) yang menyatakan bahwa struktur modal berpengaruh signifikan terhadap profitbalitas. Hasil ini juga sejalan dengan temuan Addae, Baasi, dan Hughes (2013) yang menunjukkan bahwa struktur modal berpengaruh negatif terhadap profitabilitas, dimana semakin tinggi rasio hutang maka semakin tinggi beban bunga dan cicilan utang pokok yang harus ditanggung oleh perusahaan.

Hasil dari penelitian ini menunjukan bahwa pertumbuhan berpengaruh positif dan signifikan terhadap profitabilitas perusahaan pertambangan. Pertumbuhan perusahaan yang menggambarkan perubahan kekayaan perusahaan maupun peningkatan kinerja perusahaan terbukti berpengaruh positif dan signifikan terhadap profitabilitas perusahaan. Pertumbuhan perusahaan memengaruhi profitabilitas perusahaan melalui aktiva yang dimiliki. Hasil ini sesuai dengan hasil penelitian yang dilakukan oleh Farhana, Susila dan Suwendra (2016) yang menyatakan bahwa terdapat pengaruh positif dan signifikan antara pertumbuhan penjualan terhadap profitabilitas perusahaan. Namun hasil ini berbeda dengan temuan Putra dan Badjra (2015) bahwa pertumbuhan perusahaan tidak berpengaruh signifikan terhadap profitabilitas perusahaan.

Ukuran perusahaan pada penelitian ini terbukti tidak berpengaruh signifikan terhadap profitabilitas perusahaan. Pengaruh yang tidak signifikan ini diakibatkan oleh semakin besar ukuran suatu perusahaan, maka perusahaan tersebut akan membutuhkan biaya yang semakin besar untuk menjalankan aktivitas operasionalnya seperti biaya tenaga kerja, biaya administrasi dan umum serta biaya pemeliharaan gedung, mesin, 
kendaraan dan peralatan sehingga akan mampu mengurangi profitabilitas perusahaan. Hasil penelitian ini sesuai dengan hasil penelitian yang dilakukan oleh Setiadewi dan Purbawangsa (2015) bahwa ukuran perusahaan tidak berpengaruh signifikan terhadap profitabilitas perusahaan. Senada dengan hasil penelitian Rikalmi dan Wibowo (2016) yang menunjukkan bahwa ukuran perusahaan tidak berpengaruh terhadap profitabilitas. Namun hasil penelitian ini bertolak belakang dengan penelitian yang dilakukan Ambarwati, et al (2015) bahwa ukuran perusahaan berpengaruh signifikan terhadap profitabilitas.

Likuiditas pada penelitian ini terbukti berpengaruh negative dan signifikan terhadap profitabilitas perusahaan. Hal ini menunjukan meningkatnya likuiditas akan mengakibatkan menurunnya pendapatan dan laba. Likuiditas yang tinggi akan mengakibatkan kas menganggur tinggi, hal tersebut tentu saja tidak menguntungkan perusahaan dan sebagai akibatnya profitabilitas akan rendah. Dengan demikian analisis yang dapat diberikan adalah bahwa cash ratio yang sangat tinggi akan menurunkan profitabilitas perusahaan. Hasil penelitian ini mendukung hasil penelitian yang dilakukan oleh Novita (2015) yang menyatakan bahwa likuiditas berpengaruh signifikan terhadap profitabilitas perusahaan.Namun hasil penelitian ini tidak mendukung hasil dari penelitian Rohmawati (2014) yang menyatakan bahwa likuiditas tidak berpengaruh signifikan terhadap profitabilitas.

\section{KESIMPULAN DAN SARAN}

\subsection{Kesimpulan}

Berdasarkan hasil pengujian hipotesis dan pembahasan, maka dapat dibuatkan kesimpulan sebagai berikut:

1. Struktur modal berpengaruh negatif dan signifikan terhadap profitabilitas..

2. Pertumbuhan perusahaan berpengaruh positif dan signifikan terhadap profitabilitas.

3. Ukuran perusahaan berpengaruh positif dan tidak signifikan terhadap profitabilitas.

4. Likuiditas berpengaruh negatif dan signifikan terhadap profitabilitas..

5. Hasil uji F statistik menunjukkan bahwa Struktur Modal, Pertumbuhan Perusahaan, Ukuran Perusahaan, dan Likuiditas secara simultan berpengaruh terhadap Profitabilitas dengan besar pengaruh variabel Struktur Modal, Pertumbuhan Perusahaan, Ukuran Perusahaan dan Likuiditas terhadap Profitabilitas yang dapat diterangkan oleh model persamaan ini adalah sebesar $67,14 \%$. 


\subsection{Saran}

\subsubsection{Saran Bagi Pihak Investor}

Berdasarkan hasil penelitian yang dilakukan, terbukti bahwa struktur modal, pertumbuhan perusahaan dan likuiditas memiliki pengaruh yang signifikan terhadap profitabilitas perusahaan. Sehingga disarankan kepada pihak investor hendaknya memastikan pihak manajerial perusahaan mengelola struktur modal dengan seefisien dan seefektif mungkin. Kemudian investor hendaknya mempertimbangkan bagaimana manajerial memanfaatkan dan mengelola segala sumber daya yang dimiliki perusahaan untuk meningkatkan pertumbuhan usahanya karena hal tersebut dapat berpengaruh terhadap profitabilitas perusahaan.

\subsubsection{Saran Bagi Peneliti Selanjutnya}

Bagi peneliti selanjutnya disarankan untuk memperpanjang periode sampel penelitian. Penelitian ini menggunakan variabel dependen (profitabilitas) yang dibentuk oleh variabel dependen (struktur modal, pertumbuhan, ukuran perusahaaan dan likuiditas) hanya sebesar $67,14 \%$ dan sisanya sebesar $32,86 \%$ dipengaruhi oleh beberapa variabel lain yang berpengaruh terhadap profitabilitas.

\section{DAFTAR PUSTAKA}

Addae, A. M., Nyarko-Baasi, M., \& Hughes, D. (2013). The Effects of Capital Structure on Profitability of Listed Firms in Ghana. European Journal of Business and Management, 5(31), 215-229.

Afriyanti, Meilinda. (2011). Analisa Pengaruh Current Ratio, Total Asset Turnover, Debt To Equity Ratio, Sales dan Size Terhadap Return On Asset (Studi Pada Perusahaan Manufaktur di BEI PERIODE 2006-2009), Jurnal, Universitas Diponegoro.

Akeem, B. (2014). Effects of Capital Structure on Firm's Performance: Empirical Study of Manufacturing Companies in Nigeria. Journal of Finance and Investment Analysis, vol 3, no 4, 39-57.

Ambarwati, Novi Sagita., et al. (2015). Pengaruh Modal Kerja, Likuiditas, Aktivitas dan Ukuran Perusahaan Terhadap Profitabilitas Pada Perusahaan Manufaktur yang Terdaftar di Bursa Efek Indonesia. E-Jurnal S1 Akuntansi Universitas Pendidikan Ganesha, Vol. 3 No. 1, Hal. 1-11. 
Brealey, A Richard, Stewart C. Myers and Marcus, J. Alan.(2008). Dasar-dasar Manajemen Keuangan Perusahaan jilid 2. Jakarta: ErlanggaDawar (2015)

Fahmi, Irham. (2012). Pengantar Pasar Modal, Panduan Bagi Para Akademisi Dan Praktisi Bisnis Dalam Memahami Pasar Modal Indonesia. Bandung: Alfabeta.

Farhana, Cintya Dewi., Susila, Gede Putu Agus Jana., dan Suwendra, I Wayan. (2016). Pengaruh Perputaran Persediaan dan Pertumbuhan Penjualan Terhadap Profitabilitas. Jurnal Jurusan Manajemen, Vol.4, Issue. 1.

Kaur, Harsh Vineet and Singh, Sukhdev. 2013. "Managing Efficiency and Profitability Through Working Capital: an Empirical Analysis of BSE 200 Companies". Asian Journal of Business Management 5(2): pp 197-207.Novita (2015)

Rodoni, Ahmad., dan Ali, Herni. 2010. Manajemen Keuangan. Jakarta: Mitra Wacana Media.Rohmawati (2014)

Safrida, Eli. 2008. "Pengaruh Struktur Modal dan Pertumbuhan Perusahaan Terhadap Nilai Perusahaan pada Perusahaan Manufaktur di Bursa Efek Jakarta”, Tesis.

Sundjaja, R.S., dan Barlian, I. 2012. Manajemen Keuangan. Edisi Kedua. Jakarta: Literata Lintas Media.

Van Horne, K., James, C., dan Wachowicz, John M. 2012. Fundamentals of Financial: Management Prinsip-Prinsip Manajemen Keuangan. Penerjemah: Dewi Fitriasari dan Deny Arnos Kwary. Jakarta: Salemba Empat. 